\title{
Modern and Postmodern Views of Education that Shape EFL Mentoring in the Teaching Practicum
}

\section{Visiones modernas y posmodernas de la educación que modelan el acompañamiento en la práctica pedagógica de la enseñanza del inglés}

\author{
Sandra Ximena Bonilla Medina' \\ Yolanda Samacá Bohórquez ${ }^{2}$
}

Citation/ Para citar este Artículo: Bonilla, S. y Samacá, Y. (2020). Modern and Postmodern Views of Education that Shape EFL Mentoring in the Teaching Practicum. Colomb. Appl. Linguistic. J., 22(1), pp. 55-68.

Received: 04-Mar.-2019 / Accepted: 02-Apr.-2020

DOI: https://doi.org/10.14483/22487085.14576

\begin{abstract}
Educational settings are now characterised by ethnic, cultural, linguistic, sociocultural and epistemological diversity. This article analyses epistemological diversity as an important factor in shaping teacher education programmes. This involved exploring how teacher-educators and student-teachers align themselves or negotiate modern and postmodern views of education. The research employed a narrative analysis-based on a qualitative methodology to discuss the effects of modern and postmodern views of knowledge construction and pedagogical action during the English Teaching practicum at a state university in Bogota. The findings suggest that, even though teacher-educators and student-teachers position themselves with discourses of generational change regarding conceptions of knowledge construction, there is a tendency to shape practices based on the ideals of fixed-defined generations (e.g. old, young) who have fixed views of education (old/traditional, young/contemporary) which consequently give particular shapes to pedagogical actions.
\end{abstract}

Keywords: language teaching, mentoring, modern and postmodern generations, student-teachers, teaching practicum, teacher educators

\section{Resumen}

Los entornos educativos de hoy en día se caracterizan por diferentes tipos de diversidad (por ejemplo, étnica, cultural, lingüística, sociocultural y epistemológica). En particular, este artículo analiza la diversidad epistemológica como un factor importante que determina los programas de formación de maestros. Se aborda esta diversidad explorando cómo los formadores de maestros y los maestros en formación se alinean o negocian puntos de vista modernos y posmodernos de la educación. Utilizando una metodología cualitativa basada en narrativas, este informe de investigación analiza los efectos de las visiones modernas y posmodernas en la construcción del conocimiento y la acción pedagógica durante la práctica pedagógica del inglés en una universidad pública de Bogotá. Los hallazgos revelan que, a pesar de que los formadores de docentes y

1 Universidad Distrital Francisco José de Caldas. ORCID (D) https://orcid.org/0000-0002-6625-501X. sxbonillam@udistrital.edu.co

2 Universidad Distrital Francisco José de Caldas. ORCID https://orcid.org/0000-0003-0072-073X. ysamacab@udistrital.edu.co 
docentes en formación se posicionan a favor de los discursos de cambio generacional con respecto a las concepciones de la construcción del conocimiento, existe una tendencia a moldear las prácticas en los ideales de generaciones fijas definidas (por ejemplo: jóvenes y mayores) que tienen puntos de vista fijos de la educación (antiguo /tradicional, joven/ contemporáneo) y, en consecuencia, esos puntos de vista producen formas particulares de las acciones pedagógicas.

Palabras clave: enseñanza de lenguas, acompañamiento, generaciones modernas y posmodernas, maestros en formación, práctica pedagógica, formadores de maestros

\section{Introduction}

As teacher educators (TEs) and practicum mentors, we claim that the teaching practicum is an insightful space and process in student-teachers' (STs) formation that involves active mentoring3 between STs and TEs constituting an opportunity for them to experience, value and confront their understandings of language teaching and becoming a language teacher in real-life contexts. This context is a dynamic environment where diverse issues arise regularly, causing TEs and STs to construct and reconstruct principles and methodologies to cope with daily classroom and school experiences. Experience and critical reflection on teachers' knowledges and identities in an authentic teaching and learning environment are significant to STs' future practice (Bailey et al., 1996; Borg, 2004; Johnson, 2009; Lortie, 1975; Zeichner, 1996, 2002). In this vein, contextual factors are crucial to establishing an atmosphere of reflection in the mentoring process ${ }^{3}$. Bearing in mind the relevance of context to this exercise, we reflected on how modern and postmodern views that affect society may also affect the teaching practicum. This interest emerged from the consideration of the clash between the influence of the modern perspectives that TEs were educated from and the influence of the postmodern views that underlie the contemporary education of STs.

3. Mentoring is defined here as the accompaniment developed by teacher educators to student teachers in the practicum process which entails a more horizontal relationship.
We assumed that due to the influence of modern and postmodern visions of education on the participants in the practicum, mentors, STs, and cooperating teachers ${ }^{4}$ will be involved in the negotiations necessary to cope with pedagogical action. This assumption is based on situations reported in previous studies. For instance, Zárraga, (1998) found that mentors sometimes experience resistance from STs to take their expertise into account. Conversely, on other occasions, STs follow mentors' advice religiously, thereby limiting them to just what mentors suggest. Thus, practicum supervisors ${ }^{5}$ sometimes become dominant entities who can limit STs' expressiveness and creativity (Bonilla $\&$ Mendez, 2008) because the diversity of mentoring, communication and teaching conceptions they hold lead to complex interactions and dynamics, becoming sources of tension (Bradbury \& Koballa, 2008).

Nonetheless, there are other situations that emerge in this process that demonstrate positive outcomes of constructing relationships with mentors. Hudson (2010) describes how mentors and mentees' personal qualities contribute to building a comfortable relationship that helps STs recognise and name the different knowledges of their practices that will definitely shape their views on teaching. In analysing mentors and STs as historical individuals, we can argue that both TEs and STs may adhere to different views on the educational process (Bernete, 2007; Rueda, 2008; Rueda \& Quintana, 2004). In this scenario, the practicum interactions may become complex as reality may also be perceived differently.

There is a scarcity of research that directly address the mentorship process during English practicum in the local context. However, after reviewing related research reports, we found valuable aspects that touched on mentorship. CastañedaPeña, Rodríguez-Uribe, Salazar-Sierra, and Chala-

4. Cooperating teachers are the primary supervisors of studentteachers at school. They are the teachers who help STs understand their role within the educational setting they are conducting their teaching practicum.

5. This article makes a distinction between a advisors and a mentor. The former indicates a hierarchy in the levels of power and decision making, while the latter implies a negotiation of power relationships that allows an exchange of roles. 
Bejarano (2016) highlight STs' strong relationship with their pedagogical advisors at the pedagogical, social and emotional level. Castañeda $\varepsilon$ Aguirre (2018) and Lucero \& Roncancio (2019) highlight STs' perceptions of their mentors, appraising their guidance as a key feature in how they overcome problems they encounter as teachers.

Although these findings support the positive relationships with mentors stated above, there are others that create tensions, such as the ones reported also in Lucero's (2019). They relate to the high anxiety level that sometimes STs face with their mentors because of their insufficient accompaniment in the process or their only-transmitted instrumentalized teaching techniques and "survival" practices in the TP. In this way, we agree with this author when asserting that "mentor teachers' views about the language and its teaching, as well as the how and why they interact with pre-service teachers, constitute a model to follow for the subsequent generations of English language teachers."

This paper is situated in the field of teacher education, and is a critical reflection on how behaviours (ways of living and actions) have impacted different generations in the evolution of society. This is what Bauman (1999) described as the effects of modern and postmodern perspectives. These perspectives have been defined as historical and cultural conditions arising from the post-industrial process of post modernisation, bringing changes in patterns of production and consumption, leisure and work (Bovero, 1993; Lyotard, 1992). Taking the view that society is the frame of reference to develop educational actions, this impact causes the need to reflect on how generations are affected by these modern and postmodern perspectives. In this sense, generations of TEs and STs may find diverse ways of acting during the practicum. This transformation of generations might have also transformed and made the mentorship process more complex (Phompun, Thongthew, \& Zeichner, 2013). Different beliefs about education, behaviours and ideas of education create the complexity found in these interactions. It is important that the practicum context is seen as a space where generations meet with each other to analyse the impact of cultural movements on both mentors and their mentees.
This study focuses on TEs' and STs' descriptions of their interactions when discussing the role of teaching practicum in their pedagogical formation. It was developed in an undergraduate teacher education programme in ELT of a State University of Bogotá, Colombia. The authors focused on the accounts of mentors and students in a bid to recognise how they make pedagogical decisions. The narrations presented in this paper deal with the ideas discussed in those interactions related to the ownership of knowledge or the shape of pedagogical action in the frame of modern and postmodern transformations.

\section{Literature review}

\section{A historical frame: Evolution of education from a modern to postmodern society}

The enlightenment and industrialisation era mark the emergence of science and scientific inventions. This has shaped society into an objective entity for which finding the truth is the primary duty men have.

In this way, knowledge is valued and tested according to the verifiable findings generated from scientific research. This period is described as the modern era and has impacted educational research as well as educational approaches and paradigms (Crotty, 1998). In education, this world view is reflected in the behaviourist perspectives of teaching in which education is more valued if the behavioural results are provided and explained (Popkewitz, 1984; Welko, 1993). In addition to the impact on educational research, education in that frame embodies an attempt to find universal concepts. Therefore, knowledge becomes transmitted from teachers to students without it being questioning. In this fashion, the transmission of knowledge takes the form of repetition and memorisation (Wink, 2005).

An awareness of this reality has been advocated by postmodernist thinking which, contrary to modernist worldviews, has placed subjectivity in the centre. In Crotty's (1998) words, this is in reaction to the modern worldview, which has been censured 
as the movement of rationality, logical explanations and instrumentality. From the postmodern view, all of these attempts to describe reality are criticised for attempting to provide a black and white picture of reality in which the individuals' perspectives are hidden and socio contextual relationships are not taken into account to evaluate the judgements of truth. Therefore, in postmodern paradigms, knowledge is acknowledged not to be universal but relative to contexts, conditions and people's views. In the field of education, this view is reflected in the growth of progressivism which, spearheaded by Dewey in USA, enhanced the idea of freedom and equity (Crotty, 1998; Denzin E Lincoln, 2008; Robson, 2011). These ideas have grown in different educational decisions that seem to have transformed the whole idea of teaching and education in general. Schools and other educational institutions seem to have started to take different forms; experiential education has taken importance as intercultural and sociocultural approaches, and student-centred approaches have been advocated (Byram E Fleming, 1998; Kumaravadivelu, 2001; Wells, 2006).

For authors such as Cakir (2012), Pardo Rodríguez (2011)1, Rizo (2002), and Scotland (2012), postmodernism reflects a crisis of modernity. In the former, emphasis is placed on particular contextual situations. There is also recognition of the effects of mass media as well as the free market domination (Bauman, 1999; Castells \& Alaminos, 2002; Ferrés, 2003; Kenway, 1998; Levy, 2007; Lyotard, 1992; McLaren, 1997). This particular characteristic of market domination has been more apparent due to the internet (the world of internet and online practices, according to Bauman, 1999). From this view, the strength with which new technologies have become part of educational changes and how that has transformed the role of teachers and education in general cannot be denied (Wells $\&$ Claxton, 2002).

The aforediscussed perspectives have definitely formed new visions of education which have made it more complex. This complexity is evident, for example, in the dilution of the concept of knowledge with the concept of information. These terms appear to be equated as it is believed that just by having access to information, one acquires knowledge, obviating that the former is static while the latter requires a thinking process (Alvarez $\varepsilon$ Bonilla, 2009). Access to information has also engendered the belief that there are places to go for knowledge, so knowledge is ubiquitous. This is believed because contemporary social practices have made it unnecessary to move from place to place to obtain required information or knowledge (Bauman, 1999). This is how mobile devices appear to allow access to "knowledge" without needing a physical space. Consequently, educational institutions are no longer considered the sole repositories of knowledge and wisdom, as many now believe knowledge is everywhere.

\section{Generation frame: Modern and postmodern thought transforming generations}

As pointed out above, new ways of thinking appear to have shaped new behaviours too. Yet, it is necessary to point out that these changes have impacted generations in different ways. The concept of generation itself is fashioned differently. Old and new generations used to be identified by biological stage. However, nowadays, there is a multiplicity of generations which vary in their understanding and viewing of the world. Margulis and Urresti (1998) assert that younger generations are different as people now resort to cosmetic surgery to retain their youthful looks. In this sense, young is not only the person who is young in age but the ones who appear to be young. From another perspective, the generation cut between very young children, young children, teenagers and adults seems to differ in the confidence to challenge the reality of changing times (Wells \& Claxton, 2002). The young generation seem to be amenable to technological changes than the older generations. Additionally, the fluidity, dynamism, and multimodal information that can now be accessed through various electronic devices is absorbed differently by each generation. The current young generation grew up in a digital world, therefore, are judged to consciously or unconsciously adhere more to this type of information than to the behaviour and beliefs of "the Others" (Wells \& Claxton, 2002). In this context, it can be argued that these factors create generationrelated gaps between the actors in the teaching practicum: teacher educators, pre-service teachers, and cooperating teachers (Hofstede, 1991). One of 
the purposes of this study is to relate postmodern and modern views to the idea of generations in order to see how they influence mentoring practices throughout the practicum. This also necessitates the discussion teaching practicum as a concept.

\section{Reconceptualising the teaching practicum and mentorship in the context of English Language Teaching}

Bearing in mind the impact of modern and postmodern thinking on education, the TP underlies the importance of reconceptualisation mentorship during teaching practicum. Going back to the value that has been given to educational practices from a postmodern view, the teaching practicum has become a broad field of teacher education that provides STs with a chance to experience, reflect and evaluate knowledge and abilities in a school context in tandem with their own understanding of educational philosophies and theories.

Three perspectives that aid the ELT preparation process pre-service teachers go through was developed as follows: (a) effective language teaching, emphasising a technical approach to language learning. Also called teaching as doing, as knowing what to do; (b) a reflective approach to language teaching, encompassing a practical orientation that still maintains a major focus only on the EFL instructional dimension, known as teaching as thinking and doing and knowing what to do (Freeman, 1991, as cited in Crandall, 2000) and; (c) a context-sensitive pedagogy in terms of teachers and learners' development whose growth was aided by the critical reflexivity that has nourished teaching visions.

These three perspectives are grounded on those proposed by Kumaravadivelu (1994, 2001, 2005) and Canagarajah (2002) who established three principles that underpin what they call the post-method era in second language teaching: a pedagogy of particularity, a pedagogy of practicality and a pedagogy of possibility.

These ideas help us reflect beyond the latest trends in teaching and learning an L2, what works and does not work in a certain English Language
Teaching (ELT) context since the limited-method perspective does not usually suit all teaching and learning contexts (Kumaravadivelu, 2005). This entails not designing new methods but devising other ways to teach and learn a language, bearing in mind students' needs, desires, situations that the theory underlining a method cannot solve, as they depend on the learners and contexts, moving from product-oriented teaching to processoriented teaching on the one hand, and from a rigid curriculum to a more flexible one in which communication and interaction play a significant role in second language learning.

Thus, modern epistemology-derived models appear to narrowly consider the development of teaching skills, methods, techniques and classroom management replicating theories to language teaching. Therefore, as noted by Kourieos (2012), the role of the mentor and cooperating teacher is "centred on issues concerning general pedagogical knowledge dealing with general classroom management" (p. 57). Postmodern tendencies then reflect a process of supporting STs in becoming reflective and autonomous, to be able to engage in personal construction of meaning, and to theorise from practice rather than passively practice the received knowledge. Dove (1986) states that the ideal practicum should be an opportunity for mentors and experienced school teachers to partner with each other in supporting and guiding STs. Hence, mentoring switches from modelling teaching episodes to situational language teaching experiences, from the task of an experienced teacher helping a student teacher to learn how to teach, to a potential partnership that embodies mutual shaping and professional growth.

Bearing the above in mind, mentoring appears to be significant when it is seen as a process where STs and mentors are questioning and making the needs and concerns of the school context explicit in order to develop abilities for observation, self- and collective-reflection, decision making and action. In this regard, mentoring makes us reflect critically on the three ELT conceptions above-mentioned that ought to transcend the what and how limited view of teaching, to the why, whom and where of teaching, through which we not only focus on the 
instructional dimension of teaching "but also on the views we have constructed towards learning, the language itself, the language in context and in contact with others" (Samacá, 2018: 191).

STs might assume a more active and collaborative role in their learning to teach, while mentors take on the role of facilitators, raising teachers' awareness, triggering change to provide the ground for choices (Kourieos, 2012). This requires both sides to share their expertise rather than imposing them. Here, context plays a key role in the assumptions, beliefs, experiences both TEs and STs have about teaching and learning. The day-to day interactions in the school setting with the cooperating teachers and mentors may create tensions where meaning, interpretation and implementation are constantly negotiated. This is when generations influenced by modern and postmodern views need to be considered to see how they may be part of the understanding of the mentoring exercise and its transformations.

\section{Methodology}

This study was developed using a qualitative perspective (Denzin and Lincoln, 2008), with data in the shape of narratives from two mentors and two STs on their mentoring process in the practicum. This methodology was picked as it allowed the researchers to identify the participants' interpretations of their realities and the sense they made of them (Spector-Mersel, 2010). The participants' views on the phenomenon and findings were reached following an analysis of the interviews (Jovchelovitch \& Bauer, 2000). This plan was an emergent process that attempted to catch the critical moments in the practicum between mentors and STs. As researchers, our role consisted of facilitating a space for respondents to express their ideas on those interactions freely. That is why an emic perspective to elicit participant's lived experiences as insiders was highlighted over an etic researchers' perspective (Freeman, 1998). Brief narrative accounts were used as a strategy to bridge the participants' emotions with the theoretical aspects involved in the teaching practicum.

\section{The context and the participants}

The study took place in an undergraduate teacher education programme in ELT at a state university in Bogota. In order to develop a deep analysis and understanding of narratives in this project, the respondents were placed in groups of two mentors (Lilia and Margoth) and two of their STs (Lola and Luna). The interventions of three of these participants are included here as they provided the most fruitful and relevant information for this discussion. The authors of this article are language educators in the same university. For ethical considerations, all the participants' names have been changed. Convenience sampling (Merriam, 1988) was used and so teachers who dedicated more time to work at the university were invited to participate in a narrative interview (Jovchelovitch, Bauer, E Martin, 2000).

\section{Procedures for data collection and analysis}

The narratives collected explained the way mentors organised their practicum, content and procedures, as well as how they prioritise the elements involved. We let the conversation flow naturally with the intention of engaging the respondents. We intended to ascertain those ideas they consider relevant to what they do (Johnson $\mathcal{E}$ Golombek, 2002). We interviewed the participants to gather in-depth data about their experiences, feelings and expectations that related to their teaching practicum, especially the conflict points.

\section{Results}

After analysing the data, contrary to what we thought, there was no clear cut distinction between TEs' and STs' ideas to allow for a modern or postmodern classification. It was interesting to note how having modern and postmodern perspectives influenced their attitude to shaping important decisions related to how the teaching practice and the mentoring is carried out. The process did not happen in a linear but in a dynamic manner where roles were interchanged and modified by the specific situations. Within this interaction, we focused on tensions in the practicum which consisted of the divergence of points of view evidencing principles of the modern and postmodern views discussed 
above. However, points of convergence were also analysed in order to reflect that data did not show a unique perspective. The analysis involved a grounded approach to data analysis and peer triangulation review. In this article, we report two main categories of analysis. The first category deals with how modern and postmodern views of the teaching practicum influence the role of knowledge production; and the second focused on how those views seem to have come to shape pedagogical actions in their practicum.

\section{Location and ownership of knowledge}

Some of the tensions in the descriptions of STs and TEs' had to do with the question of the place of knowledge which has been claimed as one of the transformations from the postmodern generation (Lyotard, 1992). TEs and STs showed awareness of the rise of discourses related to the construction of knowledge as something derived from social interaction rather than something that is believed to be fixed and found in a specific place as was understood under the modern era (Crotty, 1998). Both parties seem to understand that when viewing education from a traditional perspective, the mentoring process might be geared towards find the teaching formulae that either theories or TEs' academic experience can provide. In most instances, STs showed an openness to recognising the diversity of sources that can provide knowledge for pedagogical action. From that premise, they take into account that this recognition might help them understand and interpret reality in diverse ways (Crotty, 1998). However, we also found that there is a tendency to relate knowledge with expertise unidirectionally as in modern perspectives crisscrossed with the idea of generations. In other words, older generations seem to be associated with unquestionable wisdom, an idea which fits the modern approach. Nonetheless, these findings appear to be balanced with the practicum participants' awareness of knowledge created in social interaction as proposed by postmodern approaches rather than fixed and located in particular places.

STs, TEs and cooperating teachers' apparent awareness of knowledge as a social construct (a postmodern view) rather than a fixed entity (modern view) is an idea that encompasses the development of STs' ability to critically analyse their practices, reflect on them, and mindfully connect those experiences to understand that the school context is culturally diverse (Kumaravadivelu, 1994, 2001, 2005). We found that STs value their cooperating teachers' knowledge as models of their own teaching:

they had the same process I have and they will continue, they will keep on, ...this is motivating, inspiring and you want to do it in the same way as they did one day to demonstrate that there exist good (teachers) ones" (sic) (Interview 1, Lola).

In the same vein, STs consider that peers provide valuable experience in their experiential learning process. STs showed that knowledge for them is not centred in the intellectuality of TEs only. Lola, for example, thinks that "everyone wants to manage their class in a different way because everyone understands it differently" (Interview 1, Lola). By expressing this, they revealed a sense of agency which reflects power to focus their attention on different sources of knowledge such as their peers and not to separate knowledge on the basis of age or expertise. They see it as a matter of "perspective and understanding'.

STs' perspectives, as the new generation, demonstrated the capacity to view knowledge as ubiquitous in any condition of the environment rather than only located in TEs. STs also showed that this point of view recognises TEs as playing an outstanding role in knowledge formation at their practicum. Even more, STs see TEs as people who are not just limited to providing knowledge, but also provide a crucial support in the practicum process. When referring to her mentor, Lola said "she is like the basis, the guide, she is the one we can ask questions about if there is any case we have queries, she provides her background..." (Interview 1, Lola).

Likewise, STs also acknowledge university advisers' support as crucial at moments such as the beginning of their pedagogical experience at schools. As Luna explains: 
[the university adviser]has followed a process with us, has taught to us, has corrected and motivated us a lot [...] She is the basis, the guide, an understanding adviser that makes us feel comfortable to ask her to clarify or resolve doubts we have, we also acknowledge her background, she is an open book. Therefore, the sessions we have with her do not only include the lesson plan revision, but also the reflection about how that lesson plan is useful to us, what we are doing and how we could do it better. (Interview 1, Luna)

These ideas are evidence of how STs positively locate TEs in a salient place of knowledge construction for their practicum. However, this consideration also goes to the extreme idea that they are wise knowledge givers who should know exactly what to do in the teaching practicum at school. This is where a tendency to situate knowledge as a factor of age becomes prominent. In other words, age factors come to bear in constructing views which appear to accommodate modern perspectives of education. In this fashion, STs become passive individuals who expect TEs' approval or disapproval for their actions within the classroom to maintain a sense of themselves. This approach to the practicum situates the mentor in a generation that possesses the experience, power, and duty to shape STs' way of teaching (Fischer \& Van Andel, 2002). Therefore, age becomes a key factor in understanding these generations and the tensions that emerge. As stated by Lola:

When we started the teaching practicum in secondary school, children had their language teachers, then it was like the confrontation with the cooperating teacher in sixth grade, the course assigned to me... because she was old and the class should be taught the way she indicated, then confrontation appeared there (sic) (Interview 1, Lola).

As seen, age played a role in the tension that built up. This appeared to be mediating the power involved in the interactions between teachers, STs and TEs. Also, in this discussion of ownership of knowledge, this modern simplified idea of just 'learning to teach' by modelling created tensions that were related to age.
Although those tensions were not constant in all these cases, according to TEs, older teachers (cooperating teachers in this case) appear to be particular about keeping their idealised place as knowledge givers. In this vein, they try to make sure the process of mentoring is carried out in a controlled environment which, at the same time, gives them the power to provide the most appropriate advice.

This phenomenon of ownership of knowledge seems to happen with mentors too. The following illustrates that point.

For me it is very compulsory that in the lesson plan they (STs) include neurolinguistics stuff, something that has to do with auditory, visual and kinestetics because [....] is children, children perception channels, this is the best way to approach children.... (sic), (interview Lilia 2).

In this case, this TE finds herself in conflict regarding what is supposed to be her ownership of knowledge. It is evident that she relies on the results of applying neurolinguistics knowledge in her practice, so she claims HER knowledge of neurolinguistics MUST be valued in any particular practice. The use of the word "compulsory" in her narrative implies that in moments of tension with STs, she has to 'oblige' them to go over those theories. TEs' process revealed in this narrative reflect control over STs' teaching showing a pedagogical action framed in the modern view. This teacher's commands also appear to be compulsory:

....and he needs to improve definitely, urgently, for the next classes I will check if they improve, that means, if they did what they had to do. In other words, (if they did improve) what it was wrong (Interview 2, Lilia).

It is clear in this case that the TE's action emphasises her control more than the TE's guidance of the process. This TE is worried about the ST incorporating the knowledge she provided when she supervised the STs' action. Meanwhile, the mentoring is centred on methodology and procedures (Lugton, 2000) rather than reflection and critical thinking. We can say that this mentoring exercise highlights a modern view of education in which power and control underline actions. 
That is, this TE feels a moral sense to correct STs' performance by following her own views of pedagogical action (Lortie, 1975). From a modern view, reality is seen from only one perspective and this appears to be mediated by age.

Other descriptions showed how this idea of control from the TEs also impacts the way they guide STs in their pedagogical action. For example, when talking about classroom management, Lilia said:

[...]it is something that is missing for them, a pedagogy of lesson control, 40 students and time goes, for a moment, they look perfect, but later on, they look like monkeys jumping from one place to another. (sic) (interview 2, Lilia)

Lilia explains here that even if STs develop great activities in their class, they do not fulfil her expectations because they do not have the control of their lessons. As is clear in her intervention, control plays an important role and its absence shows the mentoring exercise follows pre-established parameters.

Even though this seems to be negatively adjusted to TEs with a tendency for modern models of education, through their intervention, we realised that STs' and TEs' ability to recognise a shift in the place of knowledge provides a balance for teachingrelated decision making. That is, although teachers from the older generations (old cooperating teachers and TEs) appear to engage with more modern views of education, the fact that they are conscious of the ubiquity of knowledge permits a more dialogic development of the practicum. This balance, a gain for the conflictive space of the ownership of knowledge, disappointingly shows a different view on pedagogical action when this awareness is taken the extreme.

\section{Shape and form of pedagogical action: Edutainment}

Instead of showing how TEs' and STs' narratives situate them into modern and postmodern generations, this section focuses on showing how this practicum participants' awareness of the modern and postmodern transformations of education have shaped their pedagogical action. As already reported in the previous section, TEs and STs expressed the need to be aligned with the transformations that the new generations have brought. In this vein, we realised that TEs and STs view their students as new generations that belong to a more postmodern age and who, consequently, do not assimilate information in the same way previous generations did. Therefore, they tailor their pedagogical action to the students' needs but usually to an extreme in which the balance between theory and practice is affected.

In the analysis, we found that TEs and STs struggle to find the best way to attain the goals of pedagogical action in the mentoring exercise and the classroom by following a view of pedagogy that accounts for the transformations between modern and postmodern views. The TEs and STs express their belief that their pedagogical action should be more practical than theoretical. In the interpretation of the data, this seems to be related to students' claims for more entertainment to make learning enjoyable. According to Gee (2005), this appears to be an impact of the new technologies in social life and how some online corporations have tried to link entertainment with learning. According to Kenway (1998), this transformation has caused the transformation of education to edutainment. Edutainment is an increasing interest in blending education with entertainment. This idea has made teachers and students more interested in developing enjoyable activities by, for example, taking advantage of available technological entertainment as a matter of learning. This aspect appears to have shaped a different idea of what a teacher is and what pedagogical actions should be developed.

Some of the statements in Lilia's narratives reflect that this has caused an overemphasis on fun activities to judge the success of her mentoring exercise.

I start by giving them (STs) clues, so they can see that a class can be fun, there is no case to start a boring class, with a boring class and the input I give... I say: "imagine that you are preparing a class where I will be, I am one of your students, 
If I get bored in one of my classes, that lesson would be failed...in my (your) lessons, you must be fun and active, if I don't enjoy it, it is wrong. (Interview 2, Lilia)

We found that these ideas of learning by playing also provoke an imbalance between theory and practice, situating the second as the most relevant. Korthagen (2001) posits that the fact that practice is seen salient over theory causes knowledge to become trivialised and practices instrumental. As seen in our analysis, in a bid to adapt practice to more contemporary new generations of students, TEs and STs struggle to mediate with the weight of theory that should be provided to reach the goals in the learning process. This is one of the most common conflictive situations in their dialogues in the mentoring exercise and it also appears to produce particular practices which have other consequences in the practicum.

We observe that the preoccupation with providing more contemporary adaptive pedagogical direction to 'new generation' students produces heinous comparisons between STs and classroom teachers.

[...] she (cooperating teacher) was already a teacher that wanted them (students) to be sitting down, write sitting down and... we arrived with games, puzzles, drawings which they (students) liked, songs and things like that. Then, they (students) preferred us to teach their lessons (Interview 1, Lola).

In this fashion, having fun is paramount while preparing the lessons for children at school and STs create a hierarchy which situates them professionally in a higher position in relation to their classroom teachers. Apart from showing that sometimes STs adhere to an approach where reflection on their theoretical justification of their actions do not have a relevant place (Kourieos, 2012), these data show how these conceptions create new power relationships between the participants in the practicum.

The pedagogical action in mentoring seems to have an impact on this overemphasis of edutainment too. This is supported not only by TEs' discourses but also by the STs. It can be argued that these discourses produce proposals of pedagogical action which would illustrate what Bauman, (1999), Lyotard, (1992), and Mc Laren, (1997) have largely criticised as superficial views of practice and living. From this perspective, STs claim that their own teaching actions should be more practical. Then, theory that is supposed to be used to link TEs' action in their construction of knowledge is relegated, morphing education into edutainment.

One of the TEs argued that mentoring should also back up edutainment. This teacher explained that STs chiefly complain about the length of the material they have to read in class and they become resistant to negotiation. Lilia said:

\section{We take some readings and they (STs) say: "what happens is that the situation has changed, now it is not like that!" For example they (students) do not like to have "hard going" readings. They say: let's read this quickly, they want to go quickly over that, which is "too hard going". They want to cover it fast (sic, Interview, Lilia).}

As Lyotard (1992) advocates, thinking becomes lighter or superficial and this is reflected in this TE's description of the frequent conflictive situation in the mentoring exercise with STs. She explains that this usually comes up when they discuss what is relevant. She finds that TEs believe that going over long readings is an old fashioned behaviour.

What is seen in the excerpts in this category is what Lyotard (1992) described as the influence of visual consumption of information on new generations. This phenomenon is an effect of having more accessibility to information which, consequently, has foregrounded ideas of practicality confused with liberty, leading to performativity (execution of tasks to accomplish instrumental goals) (Ball, McGuire $\mathcal{E}$ Braun, 2012). In fact, this might also be an effect of the facility and speed of methods to information promoted by new technologies. STs show they do think theory is important but they also think that tackling it means to address pain; and painful experiences that must be avoided in their instruction.

6. The Spanish word used was 'ladrillo', a colloquial expression to describe a text which is really hard and incomprehensible. 
As a consequence of STs' negative conception of theory, TEs try to shape their pedagogical action by finding different solutions for this conflictive situation. The TE in the case above, for example, tries to comply with STs by providing them with less difficult readings which make them feel more comfortable and more willing to work. Thus, she prefers to evade readings that make STs expend intellectual effort. Although, in other cases, the battle between using theory as a synonym of pain makes TEs think that they must resist students pressure. Regrettably, TEs also end up choosing to oblige STs to read what they think is necessary.

Linking the results of this category with the first category, it can also be argued that the misbalance between theory and practice may reaffirm TEs' power in the ownership of knowledge. As an illustration, this TE explains that readings better occupy a secondary place and become recycled material. In this vein, from the mentor's view, contents of hardwork theory may better be observed as practical tips.

I have to offer them (STs) something more than what is in book. This is a challenge for me to achieve, it is a challenge to demonstrate that I am able to do so, that I have the capabilities. (Interview 2, Lilia)

The emphasis on asserting that SHE is the subject of her action reassures her ownership of knowledge. Consequently, this approach to knowledge becomes a transformation of mentoring which is characterised as a challenge to mediate between the relevance of theoretical knowledge in the balance given to practice. It may be maintained that this transformation is explained in terms of the trivialisation of the dimensions of teachers' knowledge (Lyotard, 1992). TEs feel they must comply with STs' ideas by reducing theoretical reflection as a consequence of attempting to be pragmatic.

An important point to revise in terms of the consequences of the mentioned trivialisation of knowledge implies that there appears to be a decrease in TEs and STs' sense of reflection over their own practices (Kourieos, 2012; Samacá, 2012). This is seen in the following TE's narrative.
. [...] if I collect the diaries there are times in which I feel that it is a summary! ...A diary is not to write summaries!, that diary has to talk to me! (Interview 1, Lilia).

TEs themselves point out that even if they push STs to reflect on what they do, they feel STs do not go beyond descriptive levels. In another example, she similarly shows how STs appear to copy models without reflecting on what they mean. In a specific case, a ST used a successful reviewed lesson plan as a template to provide new lesson plans without careful reflection of a particular situation.

It is like I see in all the lessons, the topic is the only changeable aspect, but the scheme of the lesson is exactly the same! Then, I have to say: you didn't really think about your class, did you? (Interview 2, Lilia)

The analysis conducted here permits to evidence that postmodern effects on the ideas of learning in the mentoring endeavour shapes new views of pedagogical action in TEs and STs. STs' contributions show they have a tendency to think that people (in this case, teachers and TEs) have to change in relation to the times. Conversely, TEs show they feel challenged by these discourses and this pressure produces an imbalance between theory and practice in their pedagogical decisions. TEs and STs' are challenged to shift pedagogical action and this preoccupation causes education to become understood as edutainment. This also negatively causes an interest in practice over theory, undermining the latter. In mentoring, this emphasis on practice over theory also leads to superficial views of teaching action that focuses on performativity to the detriment of reflection.

\section{Conclusion}

The findings presented in this article show how STs and TEs change behaviour and, at the same time, model different attitudes to undertake their teaching practice under a modernity vs posmodernity perspective. In the mentoring process, TEs showed awareness of the possibility to construct knowledge that allows for flexibility in guiding pedagogical actions. Nevertheless, the flexible processes 
proposed by TEs struggle with the idea of keeping control over STs' progress in their practicum. In the same line of thought, it has been argued that STs and TEs are unable to strike a balance between theory and practice. This unsteadiness trivialises the teaching and classroom contents towards instrumentalisation and undermines reflection and its role as a key factor in teacher education.

Findings also reveal that TES's and STs are aware that TEs are no longer knowledge givers. This fact appears to challenge their authority since TEs make efforts to mediate in their interactions while STs demand for their own authority. Finally, this study suggests that having continuous dialogue with STs appears to be beneficial as it balances relationships in the mentoring and practicum experience. This dialogue involves recognition of the other to be able to assume the other's values and beliefs for particular actions.

This exploration has several pedagogical implications. The first one addresses an aspect we addressed cursorily at the end of the first section. This is related to the postmodern influence on the production of knowledge as a synonym of information. As seen in that section, the difference between these two may produce actions that obscure the weight of reflection that is necessary to link theory and practice. This imbalance affects teaching in general but also the specific mentoring exercise. Therefore, in agreement with Lyotard (1992), it is necessary to increase the criteria for evaluating the sources and validity of information so more thoughtful practices are assumed and developed. Moreover, it is necessary to reflect on if the way knowledge is assumed is the result of power relations that situate older generations as experts and that these ideas are used in in acknowledgement of their ownership of knowledge. As seen in Lilia's case, her ownership of knowledge is reaffirmed by positioning herself as a more 'practical' mentor.

Although this study highlights how modern and postmodern views of society have shaped views of educational research, education and the mentoring exercise, we recognise that the limited number of participants has limited the way we can generalise these findings. With a larger number of participants and under a different study, the findings may show a different picture of the complexity of the relationship between STs and TEs or recognition of common elements may also be found which may permit the classification of clearer groups by generation.

\section{References}

Alvarez, J., \& Bonilla, X. (2009). Addressing culture in the EFL classroom. A dialogic proposal. PROFILE Issues in Teachers' Professional Development, 2, 151-170.

Ball, S. J., Macguire, M., \& Braun, A. (2012). How schools do policy: Policy enactments in secondary schools. London and New York: Routledge.

Bailey, K. M., Bergthold, B., Braunstein, B., Fleischman, N. J., Holbrook, M. P., Tuman, J., Zambo, L. J. (1996). The language learner's autobiography: Examining the "apprenticeship of observation.". Teacher learning in language teaching, 11-29.

Bauman, Z. (1999). Culture as praxis. London: SAGE publications.

Bernete, F. (2007). Comunicación y lenguajes juveniles a través de las TIC. Memoria técnica. Madrid: Injuve

Bonilla, S. X., \& Mendez, P. (2008). Mentoring in pre-service teaching: from reflection on practice to a didactic proposal. Actualidades Pedagógicas, 52, 79-90.

Borg, M. (2004). The apprenticeship of observation. ELT Journal, 58(3), 274-276.

Bovero, M. (1993). Modernidad. AAW. Individuo, modernidad, historia. Editorial Tecnos. España, 97-111.

Bradbury, L. U., \& Koballa Jr., T. R. (2008). Borders to cross: Identifying sources of tension in mentor-intern relationships. Teaching and Teacher Education, 24(8), 2132-2145.

Cakir, M. (2012). Epistemological dialogue of validity: Building validity in educational and social research. Education, 132(3), 664-674.

Canagarajah, A. S. (2002). Globalization, methods and practice in periphery classrooms. In D. Block $\mathcal{E}$ D. Cameron (Eds.) Globalization and Language Teaching, 134-150. London: Routledge.

Castañeda-Peña, H., Rodríguez-Uribe, M., Salazar-Sierra, A., \& Chala-Bejarano, P. A. (2016). Narrative events of pre-service teachers at the end of their teaching practicum with regard to their pedagogical advisor: Learnings reported. Signo y Pensamiento, 35(68), 52-64. https://doi.org/10.11144/Javeriana.syp3568.neps. 
Castañeda-Trujillo, J. E., \& Aguirre-Hernández, A. J. (2018). Pre-service English teachers' voices about the teaching practicum. HOW, 25(1), 156-173. https:// doi.org/10.19183/how.25.1.420.

Castells, M., E Alaminos, F. (2002). La galaxia internet: reflexiones sobre Internet, empresa y sociedad. Barcelona: Plaza \& Janés.

Crandall, J. (2000). Language teacher education. Annual Review of Applied Linguistics, 20, 34-55. Cambridge: University Press

Crotty, M. (1998). The foundations of social research: Meaning and perspective in the research process. London: Sage.

Denzin, N. K., \& Lincoln, Y. S. (2008). Collecting and interpreting qualitative materials. London: Sage.

Dove, L. A. (1986). Teachers and teacher education in developing countries: Croom Helm London.

Ferrés, J. (2003). Educar en una cultura del espectáculo: Barcelona: Paidós.

Fischer, D., \& Van Andel, L. (2002). Education-towards innovative school development. Retrieved from https://comenius.de/english/thematic issues/pdffiles/fischer2-warsaw-2002.pdf

Freeman, D. (1998). Doing Teacher Research: From Inquiry to Understanding. Toronto: Heinle \& Heinle Publishers.

Gee, J.P., 2005. An introduction to discourse analysis, theory and method. Routledge. USA.

Hofstede, G. (1991). Cultures and organisationssoftware of the mind: intercultural cooperation and its importance for survival: McGraw-Hill New York, NY

Hudson, P., 2010. Mentors report on their own mentoring practices. Australian Journal of Teacher Education, 35(7), 30-42.

Johnson, K. (2009). Second Language Teacher Education. New York: Routledge.

Johnson, K. E., E Golombek, P. R. (2002). Teachers' narrative inquiry as professional development. Cambridge University Press.

Jovchelovitch, S., \& Bauer, M. W. (2000). Narrative interviewing. Qualitative researching with text, image and sound, 57-74.

Kenway, J. (1998). Pulp fictions? Information, markets, and the information superhighway. In A. Carlson D, M (Ed.), Power Knowledge and pedagogy- The meaning of democratic education in unsettling times (pp 59-89). New York: Routledge.
Korthagen, F. A. J. (2001). Linking practice and theory: the pedagogy of realistic teacher education. Mahwah, N.J.: L. Erlbaum Associates.

Kourieos, S. (2012). The impact of mentoring on primary language teacher development during the practicum. Elted, 15, 57-64.

Kumaravadivelu, B. (1994). The postmethod condition: (E) merging strategies for second/foreign language teaching. Tesol Quarterly, 28(1), 27-48.

Kumaravadivelu, B. (2001). Toward a postmethod pedagogy. Tesol Quarterly, 35(4), 537-560.

Kumaravadivelu, B. (2005). Understanding language teaching: From method to postmethod: Routledge.

Levy, P. (2007). Ciberculture: The culture of digital society Barcelona: Anthropos.

Lortie, D. (1975). School teacher. A sociological study. Chicago and London: The University of Chicago Press.

Lucero, E., \& Roncancio-Castellanos, K. (2019). The pedagogical practicum journey towards becoming an English language teacher. Profile: Issues in Teachers' Professional Development, 21(1), 173-185. https:// doi.org/10.15446/profile.v21n1.71300.

Lugton, M. (2000). Problematizing the practicum. Centre for International Education, University of Massachusetts. Retrieved from http://www.aare.edu. au/98pap/dee98277.htm

Lyotard, J. F. (1992). La condición postmoderna: informe sobre el saber (p. 131617). Planeta-Agostini.

Margulis, M., \& Urresti, M. (1998). La construcción social de la condición de juventud. Consultado en https:// www.perio.unlp.edu.ar/catedras/system/files/mario margulis y marcelo urresti - la construccion social de la condicion de juventud urresti.pdf

Mc Laren, P. (1997). Pedagogía crítica y cultura depredadora: políticas de oposición en la era postmoderna. Barcelona: Paidós.

Merriam, S. B. (1988). Case study research in education: A qualitative approach: Jossey-Bass.

Pardo Rodríguez, I. (2011). ¿ Necesitamos bases filosóficas y epistemológicas para la investigación con Métodos Combinados? Empiria. Revista de metodología de ciencias sociales 22, 91-112.

Popkewitz, T. (1984). Paradigms and ideologies in educational research. London: Falmer.

Rizo, F. M. (2002). Las disputas entre paradigmas en la investigación educativa. Revista española de pedagogía, 27-50. 
Robson, C. (2011). Real world research: A resource for users of social research methods in applied settings: Wiley Chichester.

Rueda, R. (2008). Cibercultura: metáforas, prácticas sociales y colectivos en red. Revista Nómadas, 28, 8-20.

Rueda, R., \& Quintana, A. (2004). Ellos vienen con el chip incorporado. Aproximación a la cultura informática escolar: Bogotá, Universidad DistritalIDEP/Universidad Central.

Samacá, Y. (2012). On rethinking our classrooms: A critical pedagogy view. How, 19, 194-208.

Samacá, Y. (2018). Delving into pre-Service teachers, cooperating teachers and university mentors' positionings in the initial English teaching practicum. In H. A. Castaneda-Pena et al. (Eds.), ELT local research agendas I (pp. 181-200). Bogotá, co: Universidad Distrital Francisco José de Caldas.

Scotland, J. (2012). Exploring the philosophical underpinnings of research: relating ontology and epistemology to the methodology and methods of the scientific, interpretive, and critical research paradigms. English Language Teaching, 5(9), 9-16.

Spector-Mersel, G. (2010). Narrative research: Time for a paradigm. Narrative Inquiry, 20(1), 204-224.
Welko, T (1993). Behaviourism and cognitivism in education. Psychology, 30, 314.

Wells, G., E Claxton, G. (2002). Learning for life in the 21st century: Sociocultural perspectives on the future of education: Blackwell Publishing.

Wells, G. (2006). La union de las dimensiones sociales, intelectuales y afectivas de la educación para Transformar la sociedad en Transformando la escuela: comunidades de aprendizaje. 19-27.

Wink, J. (2005). Critical pedagogy: Notes from the real world. California State University: Addison Wesley Longman.

Zárraga, J. (1998). Usos Actuales de Internet por Colectivos Juveniles. Consultado en http://www. injuve.es/en/observatorio/infotecnologia/usosactuales-de-internet-por-colectivos-juveniles

Zeichner, K. (1996). Designing educative practicum experiences for prospective teachers. In K. Zeichner, S. Melnick, \& M. Gomez (Eds.), Currents of reform in preservice teacher education programs (pp. 215234). New York: Teachers College Press.

Zeichner, K. (2002). Beyond traditional structures of student teaching. Teacher Education Quarterly, 29(2), 59-64. 